\title{
Differential Sorting of Nerve Growth Factor and Brain-Derived Neurotrophic Factor in Hippocampal Neurons
}

\author{
S. Javad Mowla, ${ }^{1}$ Sangeeta Pareek, ${ }^{1}$ Hooman F. Farhadi, ${ }^{1}$ Kevin Petrecca, ${ }^{3}$ James P. Fawcett, ${ }^{1}$ \\ Nabil G. Seidah, ${ }^{4}$ Stephen J. Morris, ${ }^{1}$ Wayne S. Sossin, ${ }^{2}$ and Richard A. Murphy ${ }^{1}$ \\ ${ }^{1}$ Centre for Neuronal Survival, ${ }^{2}$ Cell Biology of Excitable Tissues Group, Department of Neurology and Neurosurgery, \\ Montreal Neurological Institute, ${ }^{3}$ Department of Physiology, McGill University, Montreal, Quebec, Canada H3A 2B4, and \\ ${ }^{4}$ Laboratory of Biochemical Neuroendocrinology, Clinical Research Institute of Montreal, Montreal, Quebec, \\ Canada H2W $1 R 7$
}

Nerve growth factor (NGF) is released through the constitutive secretory pathway from cells in peripheral tissues and nerves where it can act as a target-derived survival factor. In contrast, brain-derived neurotrophic factor (BDNF) appears to be processed in the regulated secretory pathway of brain neurons and secreted in an activity-dependent manner to play a role in synaptic plasticity. To determine whether sorting differences are intrinsic to the neurotrophins or reflect differences between cell types, we compared NGF and BDNF processing in cultured hippocampal neurons using a Vaccinia virus expression system. Three independent criteria (retention or release from cells after pulse-chase labeling, depolarization-dependent release, and immunocytochemical localization) suggest that the bulk of newly synthesized NGF is sorted into the constitutive pathway, whereas BDNF is primarily sorted into the regulated secretory

Numerous cell types secrete neurotrophins, including CNS and PNS neurons and non-neuronal cells in peripheral tissues. Once released, neurotrophins promote neuronal survival and plasticity by interacting with specific receptors on the membranes of target neurons (for review, see Thoenen, 1995; Snider and Lichtman, 1996). We know much about sites of neurotrophin production and utilization, but we know little about the mechanisms that regulate neurotrophin release from cells.

Most secretory proteins are synthesized as high molecular weight precursors that translocate into the endoplasmic reticulum (ER) and then to the Golgi stacks. There they are posttranslationally modified (Loh, 1993) and cleaved by endoproteases that separate active peptides from inactive precursors. Many precursors are cleaved within the trans-Golgi network (TGN) by furin or furin-like enzymes that act on the $\mathrm{COOH}-$ terminal side of multibasic sites (generally Arg-X-Lys/Arg-Arg) (Hosaka et al., 1991) after which they can be constitutively re-

Received Nov. 17, 1998; revised Dec. 22, 1998; accepted Dec. 31, 1998.

We thank Amgen for providing the antibody to brain-derived neurotrophic factor. This work was supported by grants from the Medical Research Council of Canada to R.A.M., W.S.S., and N.G.S., and by funding from the National Centres of Excellence Program in Neuroscience to R.A.M. and N.G.S. S.J.M. is supported by a studentship from the Iranian Ministry of Culture and Higher Education, W.S.S. is a Scholar of the EJLB foundation, and J.P.F. is supported by a studentship from the Rick Hansen Foundation.

Correspondence should be addressed to Dr. Richard A. Murphy, Montreal Neurological Institute, McGill University, 3801 University Street, Montreal, Quebec, Canada H3A 2B4.

Copyright (C) 1999 Society for Neuroscience $\quad 0270-6474 / 99 / 192069-12 \$ 05.00 / 0$ pathway. Similar results occurred with AtT 20 cells, including those transfected with cDNAs encoding neurotrophin precursor-green fluorescent protein fusions. The NGF precursor, but not the BDNF precursor, is efficiently cleaved by the endoprotease furin in the trans-Golgi network (TGN). Blocking furin activity in AtT 20 cells with $\alpha 1-\mathrm{PDX}$ as well as increasing the expression of NGF precursor partially directed NGF into the regulated secretory pathway. Therefore, neurotrophins can be sorted into either the constitutive or regulated secretory pathways, and sorting may be regulated by the efficiency of furin cleavage in the TGN. This mechanism may explain how neurongenerated neurotrophins can act both as survival factors and as neuropeptides.

Key words: NGF; BDNF; precursor; furin; constitutive secretion; regulated secretion; neurotrophin

leased (Dubois et al., 1995). In neurons, most neuropeptides are cleaved within the regulated secretory pathway not by furin-like enzymes but by prohormone convertases 1 and 2 (PC1 and PC2) (Rouille et al., 1995), which cleave precursors in immature secretory granules before or after granules bud from the TGN. Thus, proteolytic maturation of proteins destined for regulated secretion occurs at a later time point and in a different subcellular compartment than does proteolysis of constitutively secreted proteins.

Neurotrophin processing can occur in either the constitutive or the regulated secretory pathways. Fibroblasts and Schwann cells contain the constitutive secretory pathway only. They also produce furin, which cleaves neurotrophin precursors in vitro (Bresnahan et al., 1990; Seidah et al., 1996a,b), and bioactive NGF (Bunge, 1994; Singh et al., 1997), brain-derived neurotrophic factor (BDNF) (Acheson et al., 1991), and neurotrophin-3 (NT-3) (Cartwright et al., 1994). NGF can also be processed in the regulated pathway of cells exposed to viruses or plasmids encoding the NGF precursor (Edwards et al., 1988; Heymach et al., 1996; Canossa et al., 1997; Kruttgen et al., 1998).

BDNF processing appears to occur within the regulated pathway in cells that have both secretory mechanisms, including neurons. Depolarization releases BDNF from virus-infected hippocampal neurons (Goodman et al., 1996). BDNF has been detected in large dense-core vesicles of sensory neurons (Michael et al., 1997) and in brain synaptosomes (Fawcett et al., 1997). These data are consistent with a growing number of studies showing that BDNF, but not NGF, is anterogradely transported 
in neurons [Altar et al. (1997); Fawcett et al. (1998); for review, see Altar and DiStefano (1998)].

In this study, we used a Vaccinia virus (VV) expression system to directly compare the sorting of NGF and BDNF in hippocampal neurons and AtT 20 cells. Pulse-chase labeling, immunocytochemistry, and depolarization-dependent release studies suggest that under identical experimental conditions, NGF is primarily sorted to the constitutive secretory pathway, and BDNF is sorted to the regulated secretory pathway. Inhibiting furin-like enzymes alters the processing of pro-NGF but not pro-BDNF, and cold-block methods that inhibit protein exit from the TGN prevent cleavage of pro-BDNF but not pro-NGF. In addition, blocking furin activity directs some pro-NGF to the regulated pathway, suggesting that sensitivity to furin-mediated cleavage may be an important determinant in regulating neurotrophin sorting.

Some of these results have been published previously in abstract form (Mowla et al., 1997).

\section{MATERIALS AND METHODS}

Cell cultures. Hippocampal neurons were prepared according to the method of Banker and Cowan (1977) as modified by Brewer et al. (1993). Briefly, the hippocampus was dissected from embryonic day 18 (E18) mice (Charles River, Montreal, Canada), exposed to trypsin, dissociated mechanically, and grown in $60 \mathrm{~mm}$ collagen/poly-L-lysine-coated dishes. Cells from two litters of mice were plated into six dishes. Cultures were maintained in serum-free Neurobasal medium (Life Technologies, Gaithersburg, MD) containing $0.5 \mathrm{~mm}$ glutamine and $1 \times$ B27 supplement (Life Technologies). Schwann cell cultures were prepared from neonatal rat sciatic nerve as described previously (Pareek et al., 1993). AtT 20 cells and COS 7 cells were cultured as reported previously (Seidah et al., 1996a). We also used an AtT 20 cell line stably transfected with $\alpha 1$-PDX cDNA that has been described previously (Benjannet et al., 1997). Special care was taken to ensure that cells were distributed in equal numbers in dishes that were to be used for group comparisons.

$V V$ recombinants and infections. Purified recombinant VVs containing the full-length coding regions of mouse pro-NGF and human pro-BDNF (generously provided by Regeneron Pharmaceuticals, Tarrytown, NY) were constructed as described previously (Seidah et al., 1996a,b). VVs coding for $\alpha 1$-PDX were kindly provided by Dr. Gary Thomas (Vollum Institute, Portland, OR). Separate plates of cells were infected with VV encoding pro-NGF or pro-BDNF. In one series of studies, we coinfected AtT 20 cells with VV encoding pro-NGF and $\alpha 1-P D X$. VV infections were performed as described previously (Seidah et al., 1996a), except that we used a multiplicity of infection (MOI) of 1 followed by an incubation of 8-10 hr in virus-free medium before metabolic labeling. Under our experimental conditions, there was no evidence of cell death in cells exposed to VVs for the times indicated in each experiment.

Green fluorescent protein-neurotrophin fusions. cDNAs coding for proBDNF and pro-NGF were amplified using primers that eliminated the stop codons and created restriction sites for inserting neurotrophin cDNAs in frame with the coding sequence of green fluorescent protein (GFP) from EGFP-N1 (Clontech, Cambridge, UK). The GFP coding region was inserted near the region coding for the $\mathrm{C}$ terminus of the mature neurotrophin. Thus, the NGF-GFP construct coded for amino acids 1-304 of pro-NGF, and the BDNF-GFP construct coded for amino acids $1-250$ of pro-BDNF. Clones were sequenced manually (Sequenase; United States Biochemical Corporation, Cleveland, OH). AtT 20 cells growing on poly-L-lysine-coated coverslips were transfected with neurotrophin-GFP constructs using lipofectamine (Life Technologies). Three days later the cells were fixed in $4 \%$ paraformaldehyde in PBS and analyzed by epifluorescence using a Zeiss Axioskop microscope with a $40 \times$ objective.

To determine whether GFP-labeled neurotrophins were properly processed, we metabolically labeled the cells for $6 \mathrm{hr}$ with $\left[{ }^{35} \mathrm{~S}\right]$ cysteinemethionine (Cys-Met) Translabel $48 \mathrm{hr}$ after cells were transfected with the constructs, collected cell lysates and conditioned medium, exposed them to neurotrophin antibodies, and analyzed the immunoprecipitates by SDS-PAGE, as described below. We also analyzed the biological activity of secreted GFP-tagged neurotrophins by testing conditioned medium in a Trk autophosphorylation bioassay. Conditioned media obtained from nontransfected COS 7 cells or cells transfected with NGF, NGF-GFP, BDNF, or BDNF-GFP were incubated for 5 min with NIH $3 \mathrm{~T} 3$ cells engineered to express Trk A (for NGF) or Trk B (for BDNF). The cells were lysed and immunoprecipitated with anti-pan Trk 203 antibody, fractionated by SDS-PAGE, and probed on Western blot replicas with a phosphotyrosine antibody, according to the methods of Hempstead et al. (1992).

Metabolic labeling and immunoprecipitation. For pulse-chase experiments, we incubated infected cells with $1.5 \mathrm{ml}$ of Cys-Met-free DMEM containing $10 \%$ FCS and $0.5 \mathrm{mCi} / \mathrm{ml}\left[{ }^{35} \mathrm{~S}\right]$ Translabel (ICN Biochemicals, Montréal, Québec, Canada) ( $70 \%$ methionine, $30 \%$ cysteine) for 30 min. Pro-BDNF contains 10 methionines as compared with four in pro-NGF, and mature BDNF contains three methionines as compared with one in mature NGF. These differences, together with higher concentrations of methionine in the Translabel, explain why pro-BDNF and mature BDNF tend to label more heavily than pro-NGF and NGF in most figures showing metabolic labeling. Cells were washed, and the medium was replaced with an equal volume of DMEM containing $10 \%$ FCS plus twofold excess concentrations of nonradioactive cysteine and methionine for the times indicated (chase periods). In some experiments, hippocampal neurons were incubated at $20^{\circ} \mathrm{C}$ for $3 \mathrm{hr}$ in medium containing Translabel to monitor the effects of cold conditions on precursor processing.

In all experiments, conditioned media and cell lysates were brought to final volumes of $1.5 \mathrm{ml}, 750 \mu \mathrm{l}$ of which was subjected to immunoprecipitation. Samples immunoprecipitated with nonimmune rabbit $\mathrm{IgG}$ showed no bands corresponding to standards of neurotrophin precursors or products.

Immunoprecipitations were performed as described previously (Seidah et al., 1996a). For NGF, we used an affinity-purified rabbit anti-NGF IgG described previously (Murphy et al., 1993; Seidah et al., 1996a). BDNF immunoprecipitations were performed using an antibody kindly supplied by Amgen and characterized previously (Fawcett et al., 1997; Yan et al., 1997). Cell lysates and conditioned media were analyzed by electrophoresis on a 13-22\% SDS-PAGE. Gels were fixed in $40 \%$ methanol and $10 \%$ acetic acid, treated with ENHANCE (DuPont NEN, Boston, MA), and washed in $10 \%$ glycerol, all for $1 \mathrm{hr}$. Dried gels were analyzed by a phosphorimaging device (Molecular Dynamics, Sunnyvale, $\mathrm{CA}$ ), and radioactivity in each band was quantitated using the ImageQuant program. Levels of radioactivity were within the linear range of the device. Statistical significance was determined using the Student's $t$ test on a minimum of triplicate experiments.

To monitor the effects of depolarization on neurotrophin release, we infected hippocampal neurons with recombinant viruses, metabolically labeled the cells for $30 \mathrm{~min}$, and washed and incubated the cells in medium containing excess nonradioactive methionine and cysteine for 4 hr. The cells were exposed to tissue culture medium supplemented with or without $\mathrm{KCl}(56 \mathrm{mM})$ and $\mathrm{CaCl}_{2}(5.8 \mathrm{~mm})$ for $15 \mathrm{~min}$. Conditioned media and cell lysates were collected, immunoprecipitated, and fractionated by SDS-PAGE. Neurotrophin levels were estimated and compared by phosphorimager analysis. In a control experiment, we examined $\mathrm{KCl}$-induced release of endogenous secretogranin II using immunoprecipitation methods. VV/NGF-infected cultures of hippocampal neurons were treated as above, and conditioned media and cell lysates were immunoprecipitated with an antibody to rat secretoneurin kindly provided by Dr. Reiner Fischer-Colbrie (Department of Pharmacology, Innsbruck University, Austria).

Immunocytochemistry and confocal microscopy. VV/NGF-BDNFinfected AtT 20 cells and primary cultures of hippocampal neurons as well as controls consisting of uninfected cells or cells infected with wild-type VVs were rinsed with PBS, fixed for $20 \mathrm{~min}$ in $4 \%$ paraformaldehyde in $0.1 \mathrm{M}$ phosphate buffer, $\mathrm{pH} 7.4$, and permeabilized in $0.1 \%$ Triton X-100 for $10 \mathrm{~min}$. The cells were preincubated for $20 \mathrm{~min}$ in HEPES-buffered saline (HBS) containing 10\% FCS to reduce nonspecific antibody binding and exposed to 1:2000 dilutions of primary antibodies overnight at $4^{\circ} \mathrm{C}$. The cells were washed three times with HBS (5 min each) and incubated $1 \mathrm{hr}$ with CY3-conjugated goat antirabbit antibody (Jackson Laboratory, Bar Harbor, ME) diluted 1:2000 in HBS containing $10 \%$ goat serum. Cells were washed three times in HBS and mounted in a Tris-buffered glycerol mounting medium (Sigma, St. Louis, MO). 


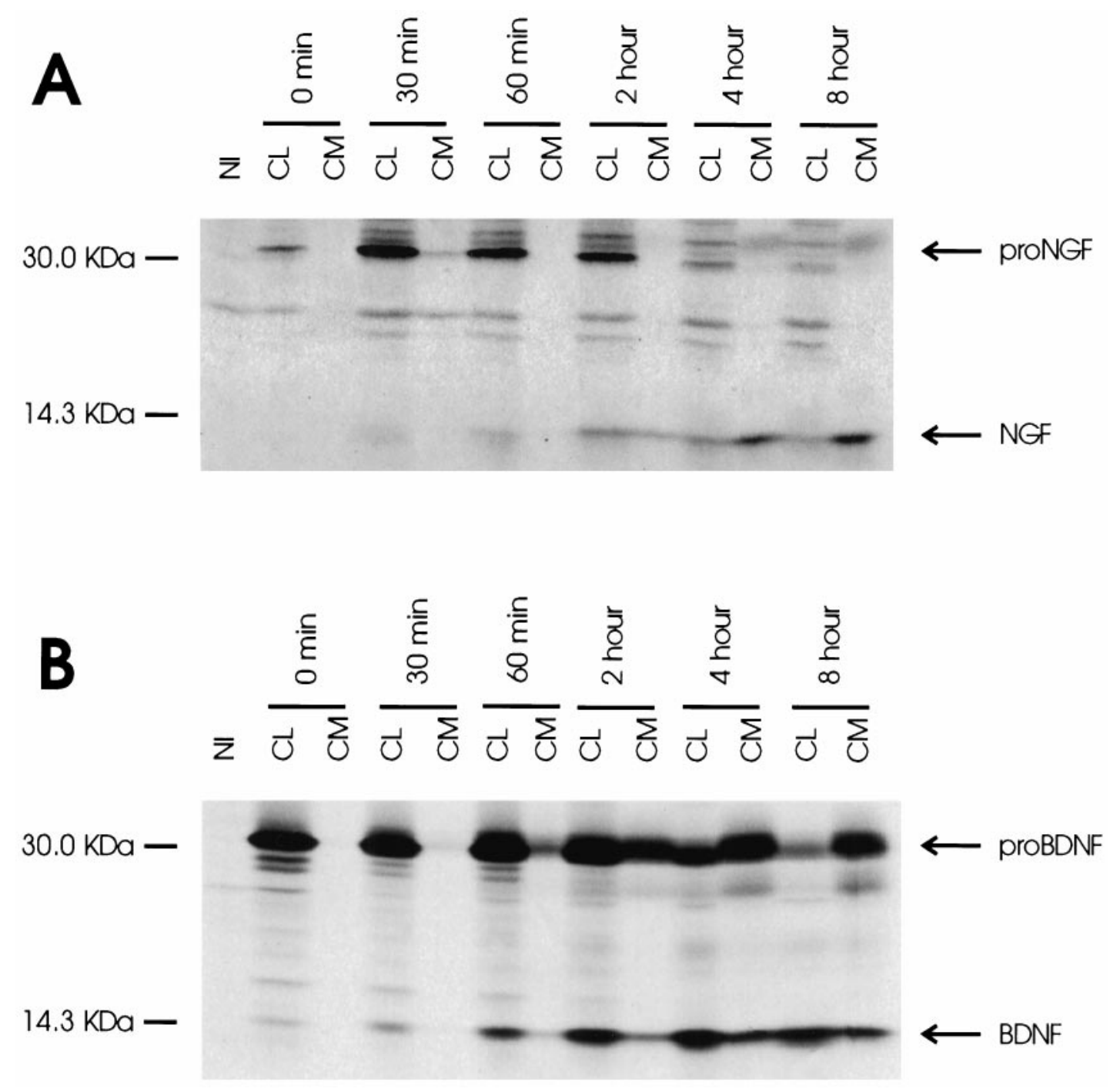

Figure 1. Pulse-chase metabolic labeling of pro-NGF $(A)$ and pro-BDNF $(B)$ in cultures of hippocampal neurons. Separate plates of cells were infected with VV encoding the NGF precursor or the BDNF precursor for $1 \mathrm{hr}$ and postincubated in fresh medium without virus for $10 \mathrm{hr}$. Cells were exposed to medium containing $\left[{ }^{35} \mathrm{~S}\right.$ ] Cys-Met for $30 \mathrm{~min}$ and chased for $0,0.5,1,2,4$, and $8 \mathrm{hr}$. Identical volumes $(750 \mu \mathrm{l})$ of cell lysates $(C L)$ and conditioned media $(C M)$ were immunoprecipitated with antibodies to NGF or BDNF or with nonimmune serum (NI; a cell lysate sample) and electrophoresed on $13-22 \%$ SDS gradient gels. Dried gels were exposed to a phosphorimaging screen.

Cells were analyzed by confocal laser scanning microscopy with a Zeiss LSM 410 inverted confocal microscope using a $63 \times, 1.4$ NA objective. Cells were excited at $543 \mathrm{~nm}$ and imaged on a photomultiplier after passage through FT 590 and LP 590 filter sets. The confocal images represent one confocal level (a depth of $\sim 1 \mu \mathrm{m}$ ) that contains the cell nucleus along with as many cell processes as were possible to image, to evaluate the peripheral distribution of secretory vesicles. There were no perceptible differences in the distribution of NGF and BDNF immunoreactivity when we scanned below and above the nucleus. All images were printed on a Kodak XLS 8300 high-resolution printer.

In some studies we used epifluorescence microscopy to compare in VV-infected AtT 20 cells the distribution of NGF and BDNF immunoreactivity with TGN38, a marker of the trans-Golgi network (Luzio et al., 1990), and ACTH, which is packaged in secretory vesicles of AtT 20 cells. Antibody to TGN38 raised in guinea pig (kindly provided by Drs. G. Banting and W. Garten, University of Texas, Southwestern, Dallas, TX) was used at a 1:50 dilution and visualized using an FITC-conjugated secondary antibody raised in goat (Jackson Laboratory) diluted 1:50 in HBS containing $10 \%$ normal goat serum. ACTH localization was performed using a monoclonal antibody (Cortex Biochem) at a dilution of 1:1000, visualized with a CY2-conjugated goat anti-mouse secondary antibody (Jackson Laboratory) diluted 1:1000 in HBS containing normal goat serum.

\section{RESULTS}

\section{Differential retention of NGF and BDNF in hippocampal neurons}

Figure 1 compares neurotrophin processing in hippocampal neurons infected with recombinant viruses encoding either pro-NGF or pro-BDNF. Figure $1 A$ shows that over an $8 \mathrm{hr}$ chase period, pro-NGF processing gives rise to mature NGF. The NGF precursor $(35 \mathrm{kDa})$ is evident in cell lysates at the start of the chase period, and within 30 min, glycosylated higher molecular weight forms of the precursor (39-42 kDa) (Seidah et al., 1996a) are evident. Levels of the precursor remain steady in cell lysates for up to $2 \mathrm{hr}$ but decrease thereafter. Small amounts of the precursor are also evident in conditioned medium sampled at 4 and $8 \mathrm{hr}$. Mature NGF (13.2 kDa) is visible in conditioned medium after 2 


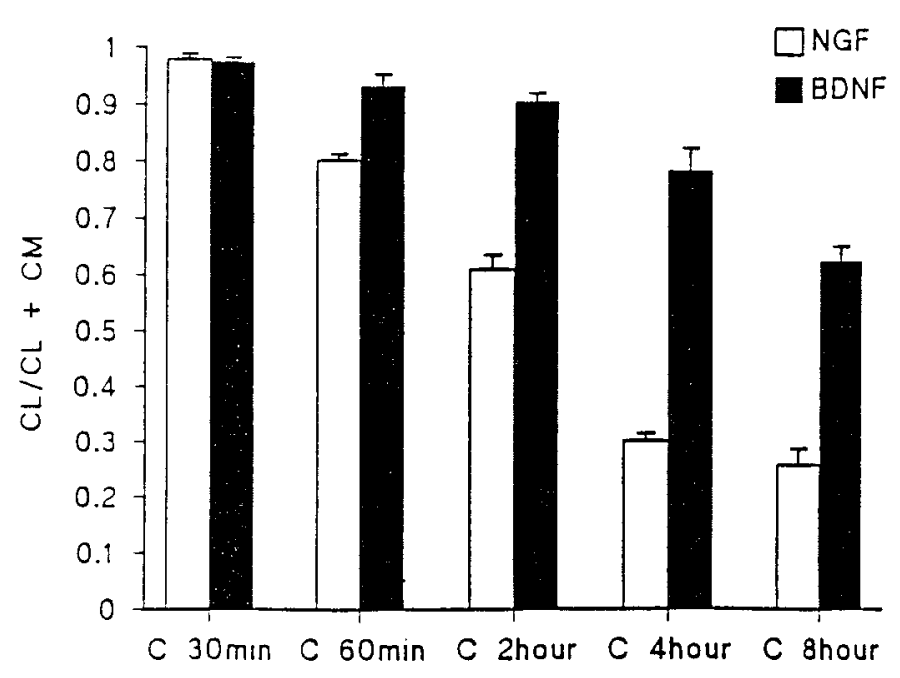

Figure 2. Kinetics of NGF and BDNF retention in hippocampal neurons. Experiments in Figure 1 were repeated three times, and the combined results were analyzed by the ImageQuant program. The ratio of mature NGF and BDNF in cell lysates $(C L)$ was compared with the total $\mathrm{NGF}$ and BDNF in $\mathrm{CL}+$ conditioned medium $(C M)$. Data show that significantly larger amounts of BDNF are retained in CL than NGF.

$\mathrm{hr}$, and at $4 \mathrm{hr}$, levels are higher than in the corresponding cell lysates. Phosphorimager analysis revealed that in samples collected at $8 \mathrm{hr}, 3.0$ times $( \pm 0.7 \mathrm{SEM})$ as much mature NGF is released into medium than is retained within cell lysates.

Figure $1 B$ shows that pro-BDNF is also processed by hippocampal neurons. Pro-BDNF (32 kDa) is evident within cell lysates in all time periods tested, with levels decreasing in samples collected at 4 and $8 \mathrm{hr}$ when levels of processed product increase. In contrast to pro-NGF, significant levels of the BDNF precursor are also evident in conditioned media in all samples collected after $1 \mathrm{hr}$, apparently because of constitutive release of the protein. Mature BDNF (14.2 kDa) is evident within cell lysates by $1 \mathrm{hr}$ and remains detectable throughout the $8 \mathrm{hr}$ period of analysis. The amount of BDNF retained in cell lysates exceeds the amount released into conditioned medium by 4.0 -fold $( \pm 1.5$ SEM) in samples collected at $8 \mathrm{hr}$.

Figure 2 presents data obtained from triplicate experiments on hippocampal neurons performed as shown in Figure 1. The figure compares the amount of processed NGF or BDNF in cell lysates as a function of the total amount of processed neurotrophin in cell lysates and conditioned media. Significantly higher levels of BDNF are retained within cell lysates as compared with NGF as early as $1 \mathrm{hr}$ after chase, and the differences increase over the $8 \mathrm{hr}$ chase period.

To determine whether hippocampal neurons are unique in their ability to retain more BDNF than NGF, we repeated the pulse-chase experiments shown in Figure 1 in AtT 20 cells, a well established cell line that contains both the regulated and constitutive secretory pathways (Burgess and Kelly, 1987). Figure 3 shows that AtT 20 cells, like hippocampal neurons, release more NGF into conditioned medium than they retain in cell lysates; the opposite occurs with BDNF. Therefore, in both neurons and AtT 20 cells, most newly synthesized and processed NGF is released from cells, whereas most processed BDNF is retained in cell lysates.

To determine whether retention of BDNF is only a characteristic of cells with the regulated secretory pathway, we repeated the experiments with constitutively secreting rat Schwann cells. Figure 4 shows that pro-BDNF is processed by Schwann cells. By $4 \mathrm{hr}$ chase, slightly higher levels of processed BDNF are evident in conditioned media than in cell lysates. By $8 \mathrm{hr}$, both mature BDNF and pro-BDNF are evident only in conditioned medium. Therefore, Schwann cells process pro-BDNF and release it, along with the BDNF precursor, into conditioned medium. Thus, the retention of processed BDNF by hippocampal neurons and AtT 20 cells is likely caused by differences in the secretory pathways of these cells and Schwann cells.

\section{Immunocytochemical localization of BDNF and NGF}

We used immunocytochemistry and confocal microscopy to assess the intracellular locations of NGF and BDNF immunoreactivity in recombinant virus-infected cells. Figure 5 shows BDNF immunoreactivity localized to punctate structures throughout the cytoplasm and in the tips of processes in both AtT 20 cells (Fig. $5 A$ ) and hippocampal neurons (Fig. $5 B$ ). In contrast, NGF immunoreactivity is distributed in the perinuclear cytoplasm of both AtT 20 cells (Fig. 5C) and hippocampal neurons (Fig. 5D) and was seldom detected as punctate in either cell type. Neither NGF nor BDNF immunoreactivity was evident in uninfected cells or in cells infected with wild-type viruses (data not shown). Detection of BDNF immunoreactivity within vesicle-like structures is consistent with the idea that BDNF is processed within the regulated secretory pathway.

Figure 6 compares the distribution of BDNF and NGF immunoreactivity with that of endogenous TGN38 and ACTH in virally infected AtT 20 cells. Cells were immunostained for $\operatorname{BDNF}(A, B, G, H), \mathrm{NGF}(C, I), \mathrm{ACTH}(E, H)$, and TGN38 $(D, F, G, I)$. Immunoreactivity for $\operatorname{BDNF}(A)$ and TGN38 $(D)$ colocalize $(G)$ as does immunoreactivity for $\operatorname{NGF}(C)$ and TGN38 $(F)$ within the perinuclear region $(I)$. BDNF immunoreactivity is also located in punctate structures that are distributed within the cytoplasm and processes of AtT 20 cells $(A, B)$ in a manner indistinguishable from $\mathrm{ACTH}(E)$. In some vesicles, the two proteins colocalize $(H)$. In contrast, NGF immunoreactivity was never seen in punctate structures under these experimental conditions. Taken together, these data suggest that BDNF is located in the TGN, as expected before sorting, and packaged within large dense-core vesicles similar to those containing endogenously produced ACTH. NGF is also located in the TGN but is not packaged or concentrated within large dense-core vesicles, which is consistent with NGF being released through the constitutive secretory pathway.

Our results suggest clear differences between the sorting of NGF and BDNF. To test whether these results arose simply as a result of the Vaccinia virus infection method, we transfected AtT 20 cells with constructs coding for GFP fused to the C-terminal region of pro-BDNF or pro-NGF and examined the distribution of the fusion proteins by epifluorescence microscopy. Figure $7 \mathrm{~A}$ shows that pro-BDNF-GFP fluorescence was localized within punctate structures in the cytoplasm and tips of cell processes. In contrast, pro-NGF-GFP (Fig. 7B) was distributed diffusely within the cell, never within punctate structures. NGF-GFP fluorescence was also less intense than that of BDNF-GFP, perhaps because of its failure to be concentrated in vesicles and its constitutive release from the cell. The differential distribution of GFP-labeled pro-BDNF and pro-NGF was similar to that obtained using the Vaccinia virus infection method. Haubensak et al. (1998) recently reported results similar to ours with respect to the localization of BDNF-GFP fusion proteins. 


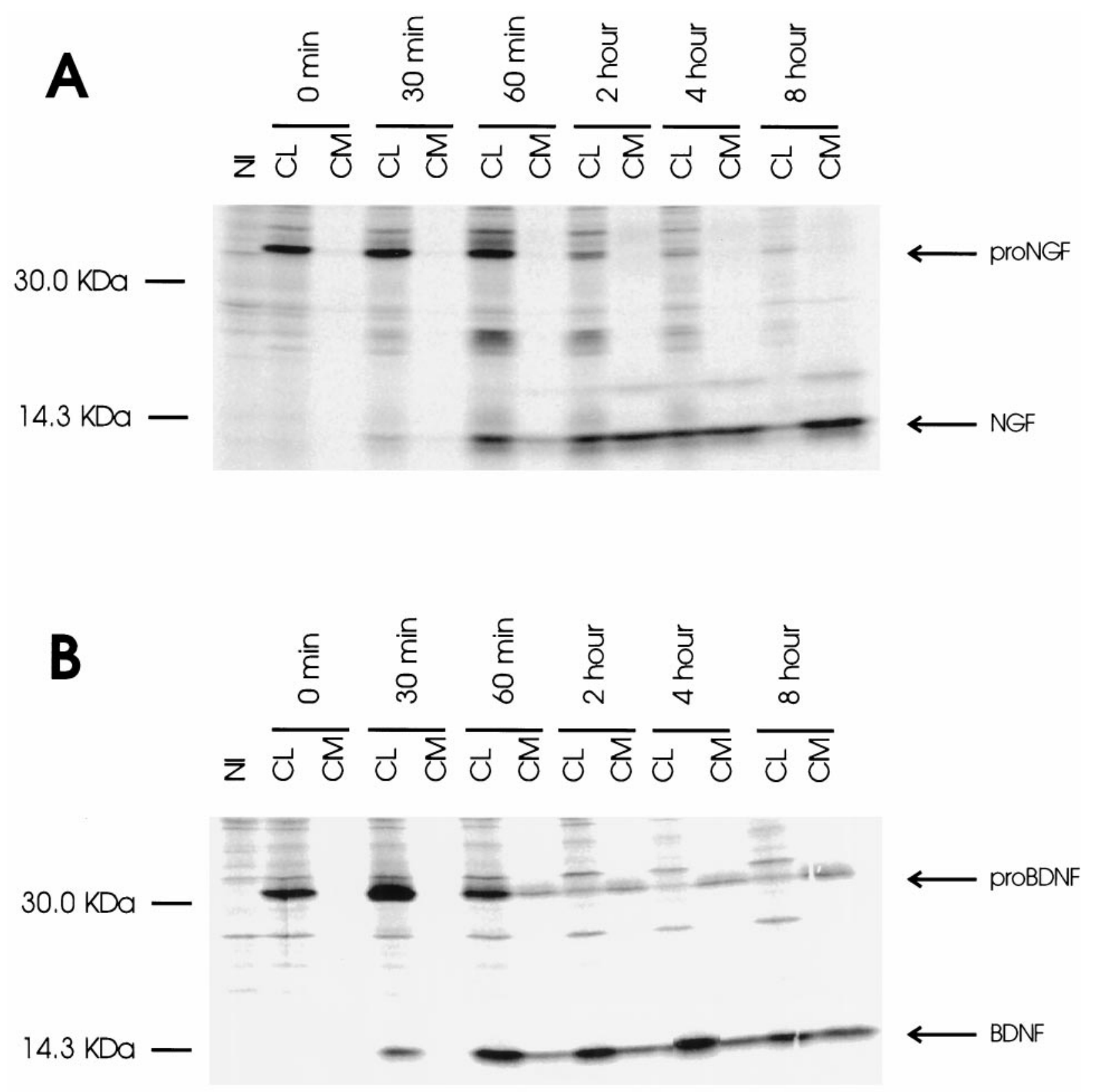

Figure 3. Pulse-chase metabolic labeling of pro-NGF $(A)$ and pro-BDNF $(B)$ production and processing in VV-infected AtT 20 cell cultures. Methods were identical to those described in the legend to Figure 1. NGF and BDNF and their precursors were measured in conditioned medium $(C M)$ and in cell lysates $(C L)$. NI is a sample of $C L$ precipitated with nonimmune serum.

We performed metabolic labeling and SDS-PAGE analyses to determine whether pro-BDNF- and pro-NGF-GFP-labeled constructs were appropriately translated and processed in these experiments. However, these experiments were unsuccessful in AtT 20 cells because of low transfection efficiency. We repeated the experiments in COS 7 cells and found that both pro-NGF-GFP and pro-BDNF-GFP were processed appropriately, without cleavage of the GFP tag, as reported previously (Haubensak et al.,1998) (Fig. 7C). We also determined that medium conditioned by COS 7 cells that had been transfected with pro-NGF-GFP and pro-BDNF-GFP was fully active in inducing Trk A and Trk B autophosphorylation, respectively, in NIH 3 T3 cells engineered to express the receptors (Fig. $7 D$ ). These data indicate that
GFP-tagged pro-BDNF and pro-NGF are processed appropriately and that conditioned media containing the precursor and mature forms of the proteins can activate their cognate receptors. Data monitoring the distribution of the neurotrophin-GFP fusion proteins further confirm our VV data indicating clear differences in the sorting and intracellular distribution of NGF and BDNF.

\section{Depolarization-induced release of BDNF from hippocampal neurons}

If $\mathrm{BDNF}$ is in the regulated secretory pathway, depolarization should promote its release. Figure 8 shows that BDNF levels in conditioned medium nearly doubled when hippocampal neurons 


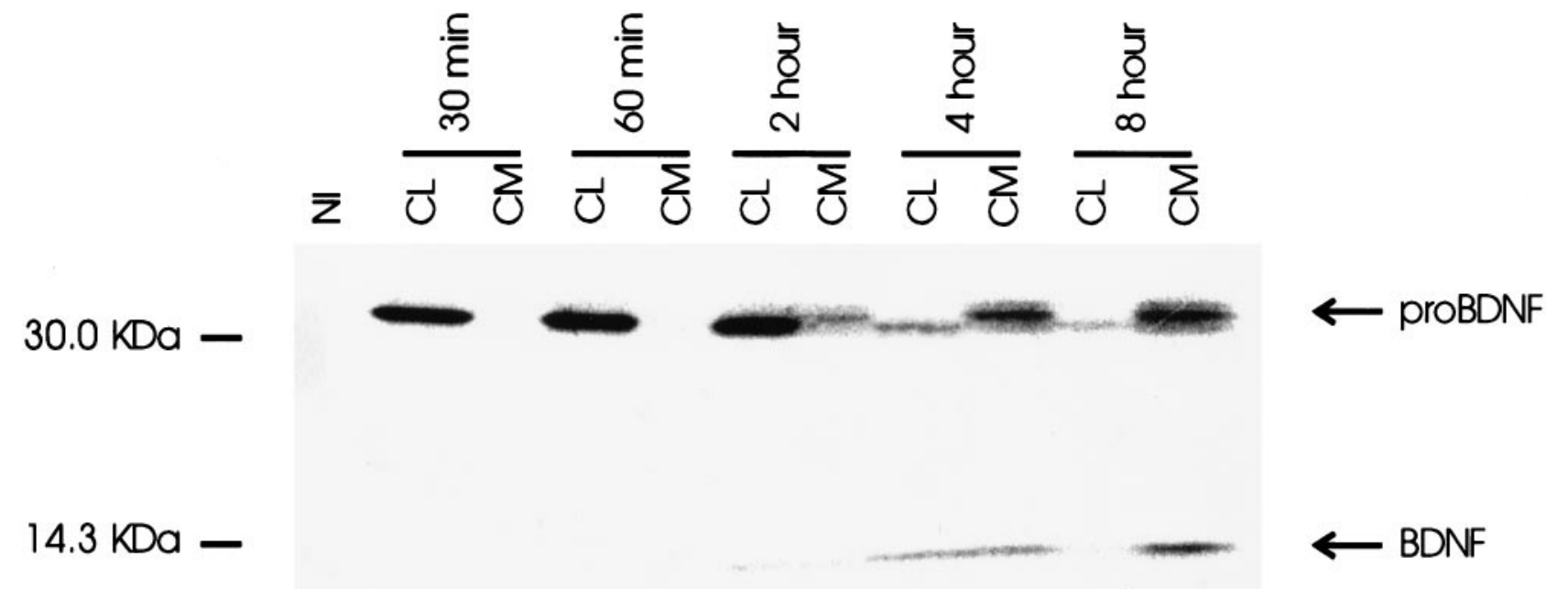

Figure 4. Pulse-chase metabolic labeling of primary rat Schwann cells infected with VV encoding pro-BDNF. Methods were identical to those described in the legend to Figure 1 . BDNF and its precursor were measured in cell lysates $(C L)$ and conditioned media $(C M)$. $N I$ is a $C L$ sample precipitated with nonimmune serum.

AtT 20

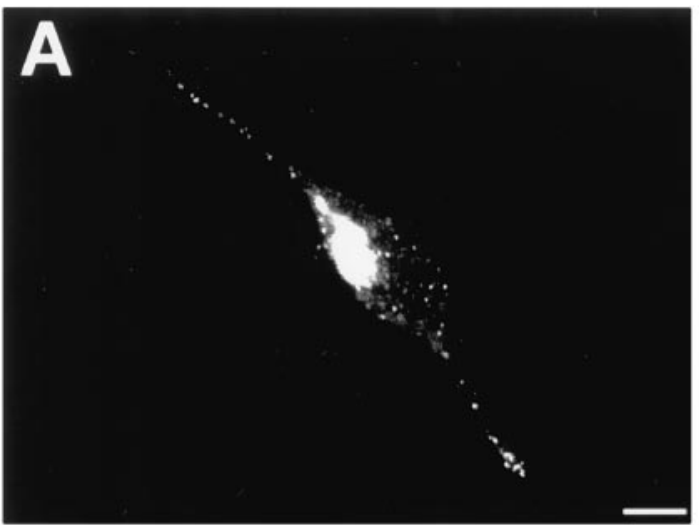

\section{BDNF}

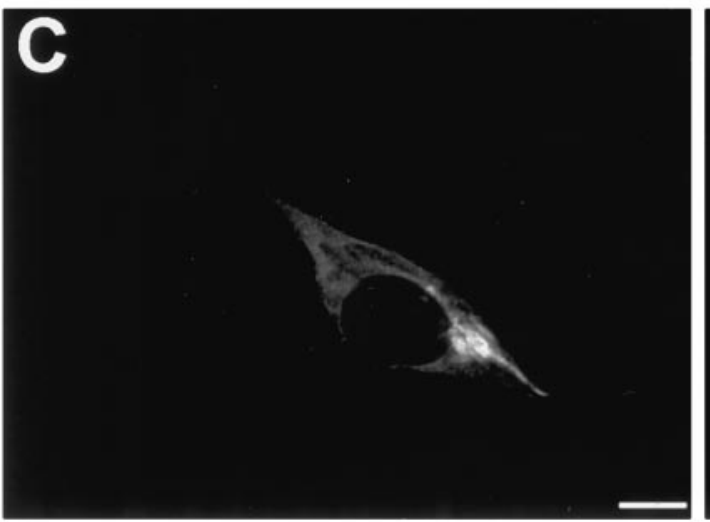

\section{Hippocampal Neurons}
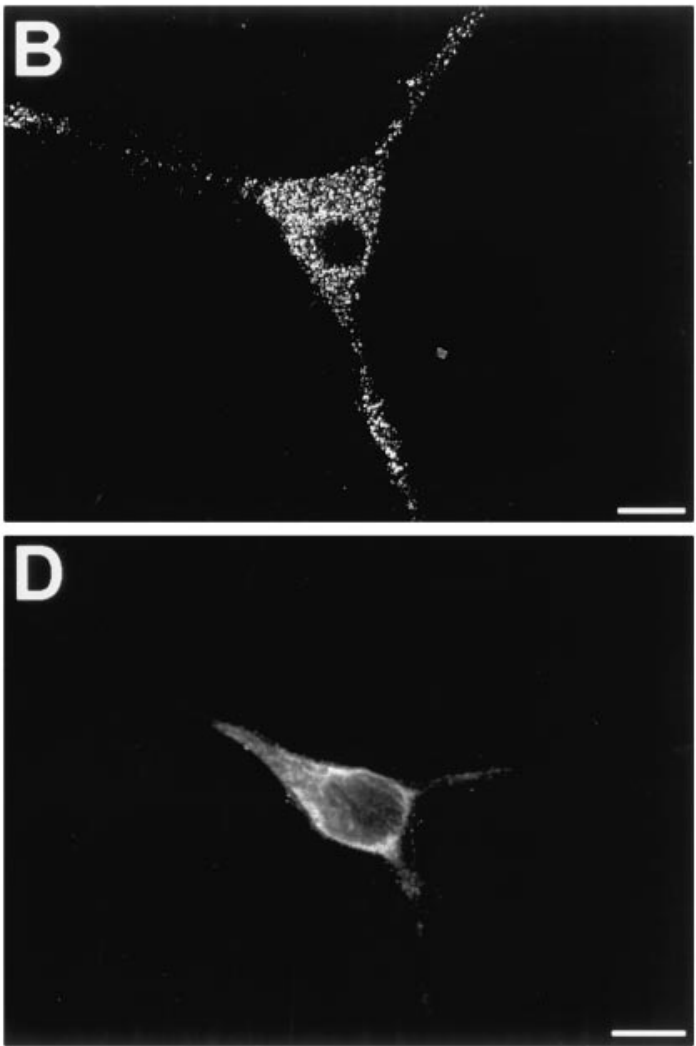

Figure 5. Confocal microscopy of AtT 20 cells $(A, C)$ and hippocampal neurons $(B, D)$ infected with VV encoding pro-NGF $(C, D)$ or pro-BDNF $(A$, $B)$. Cells were infected for $1 \mathrm{hr}$ and postincubated in the absence of virus for another $8 \mathrm{hr}$. The cultures were fixed and treated with antibodies against NGF or BDNF, followed by CY3-conjugated goat anti-rabbit IgG. Scale bar, $10 \mu \mathrm{m}$.

were exposed to $\mathrm{KCl}$; however, depolarization had no effect on NGF release. Depolarization did not promote the release of pro-BDNF or pro-NGF under these experimental conditions (data not shown). To be certain that infecting hippocampal neurons with the NGF-coding virus had not altered the regulated secretory pathway of hippocampal neurons, we monitored the effects of $\mathrm{KCl}$ depolarization on the release of endogenously produced secretogranin II, which is present in the regulated pathway. Figure 9 shows that $\mathrm{KCl}$ treatment effectively promoted secretogranin II release in cells infected with pro-NGF encoding VV. 

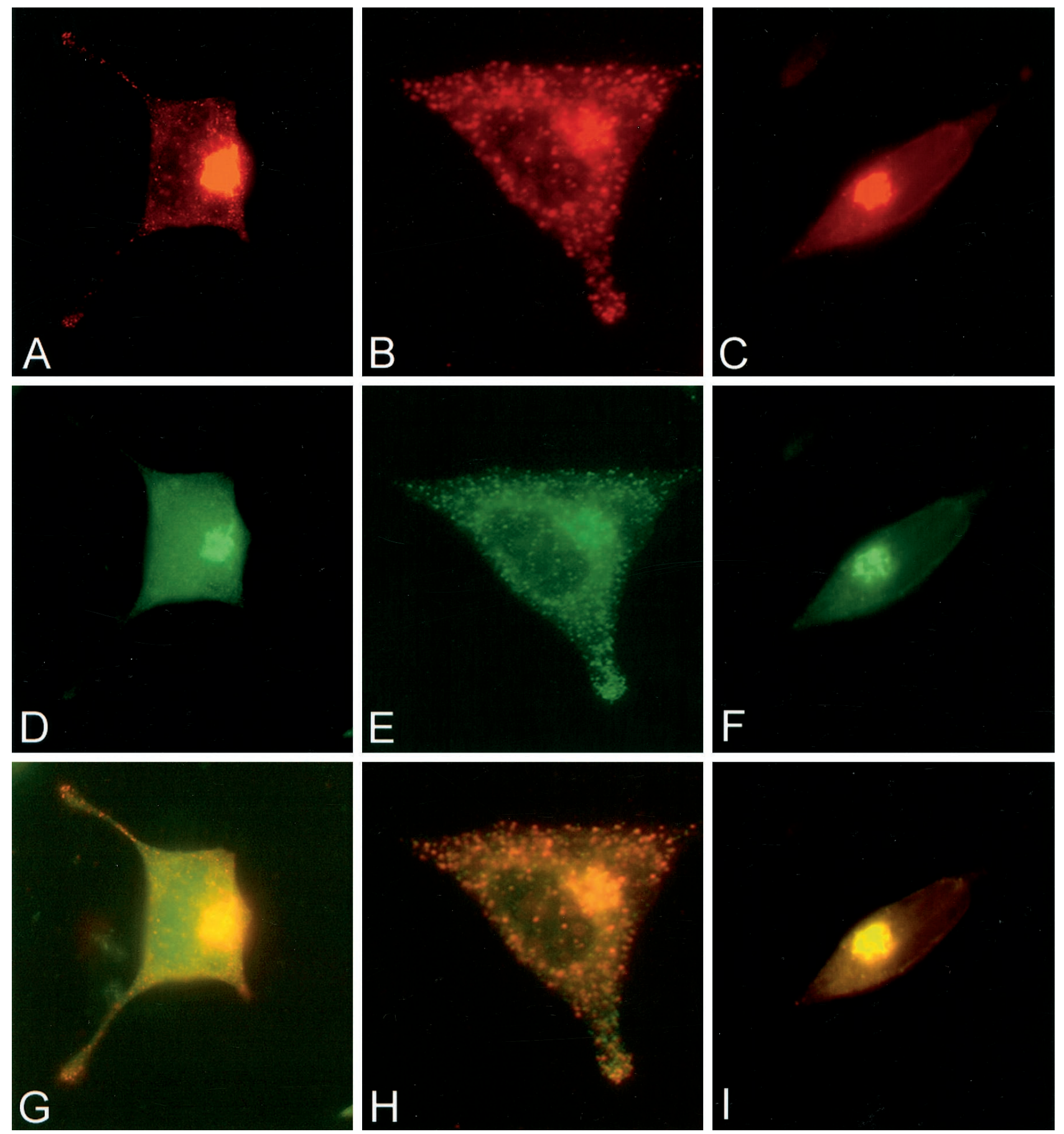

Figure 6. Double-label immunocytochemistry comparing the distribution in infected AtT 20 cells of BDNF and NGF immunoreactivity with immunostaining of endogenous TGN38 and ACTH. BDNF immunoreactivity $(A, B)$ colocalizes with TGN38 $(D)$ in the perinuclear region and with ACTH in the cytoplasm and cell processes $(E)$. $G$ is a composite of $A$ and $D ; H$ is a composite of $B$ and $E$. NGF immunoreactivity $(C)$ colocalizes with TGN38 $(F)$ in the perinuclear region but is not detectable in cell processes. $I$ is a composite of $C$ and $F$.

\section{Differential processing of pro-NGF and pro-BDNF by furin}

To further test whether BDNF and NGF are differentially sorted in cells containing both a regulated and constitutive secretory pathway, we performed three additional sets of experiments. In the first, we tested the effects of lowered temperature on the processing of the neurotrophin precursors. Cold temperatures $\left(20^{\circ} \mathrm{C}\right)$ allow precursor proteins to enter the TGN but inhibit vesicle budding from the TGN, which is an essential step for processing proteins in immature secretory granules of the regulated secretory pathway (Matlin and Simons, 1983). Therefore, precursor processing at $20^{\circ} \mathrm{C}$ must occur within the TGN. For these studies, we infected hippocampal neurons with recombinant VVs, metabolically labeled the cells, incubated them for $3 \mathrm{hr}$ at $20^{\circ} \mathrm{C}$, and analyzed the intracellular content of newly synthesized NGF and BDNF in cell lysates by immunoprecipitation methods. Figure 10 shows that significant amounts of mature NGF were generated from the NGF precursor under cold-block conditions, 

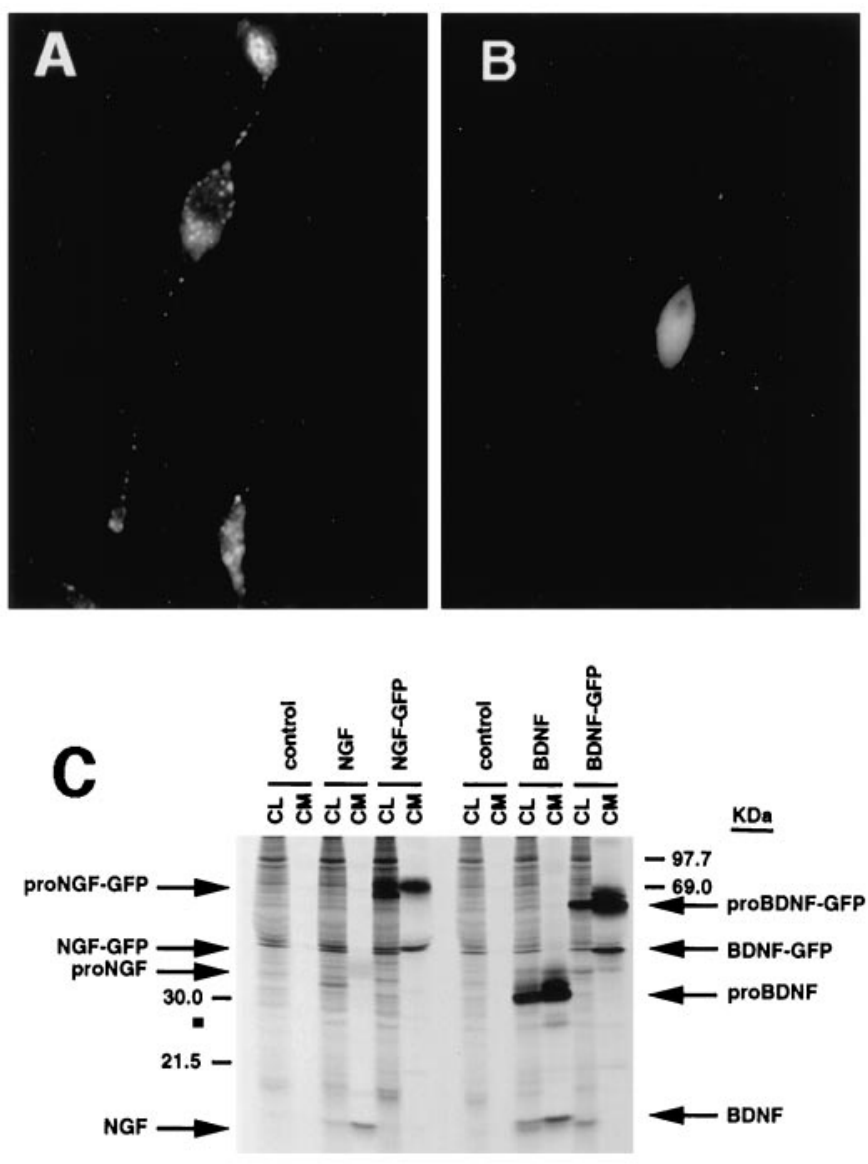

D

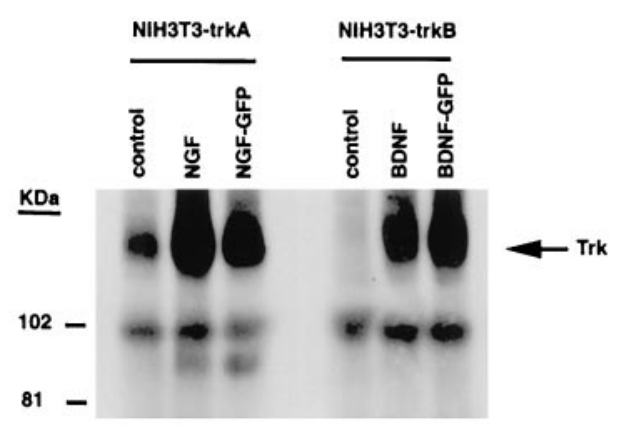

Figure 7. Expression of pro-neurotrophin-GFP fusion proteins in AtT 20 cells. Cells were plated on poly-L-lysine-coated coverslips and transfected using lipofectamine with cDNAs encoding either $(A)$ pro-NGFGFP or $(B)$ pro-BDNF-GFP. Three days later, the cells were analyzed by fluorescence microscopy. $C$, Immunoprecipitation and SDS-PAGE of metabolically labeled GFP fusion proteins from transfected COS 7 cells. $D$, Conditioned medium from pro-NGF-GFP or pro-BDNF-GFP expressing COS 7 cells activate Trk A and Trk B phosphorylation, respectively, in NIH 3 T3 cells engineered to overexpress either receptor.

whereas cold block totally inhibited the generation of mature BDNF from the BDNF precursor. Therefore pro-NGF, but not pro-BDNF, is cleaved within the TGN, probably by furin.

We also compared pro-NGF and pro-BDNF processing in the presence of $\alpha 1$-PDX, an $\alpha 1$-anti-trypsin derivative that selectively interferes with furin's ability to process precursor proteins within the TGN (Anderson et al., 1993; Watanabe et al., 1995; Vollenweider et al., 1996). In these studies, we monitored neurotrophin processing in AtT 20 cells coinfected with VVs encoding either

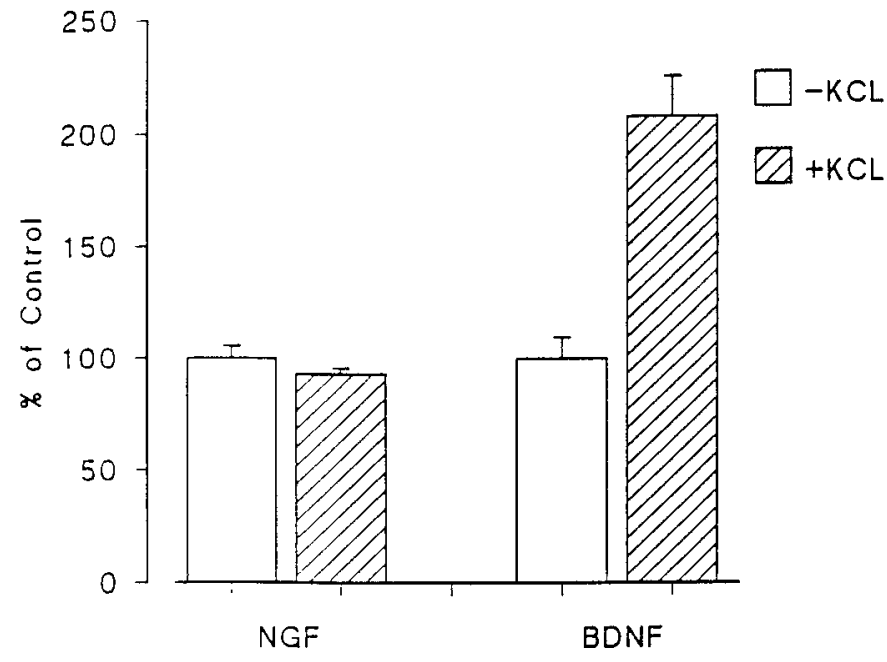

Figure 8. KCl-induced release of BDNF but not NGF from hippocampal neurons. Hippocampal neurons from E18 mice were cultured for $7 \mathrm{~d}$ and infected for $1 \mathrm{hr}$ with VV encoding pro-NGF or pro-BDNF. After $10 \mathrm{hr}$ in medium without virus, the cells were labeled for 30 min with $\left[{ }^{35} \mathrm{~S}\right]$ Cys-Met, incubated in medium without radiolabel for $4 \mathrm{hr}$, and treated with medium with or without $\mathrm{KCl}$ and $\mathrm{CaCl}_{2}$ for $15 \mathrm{~min}$. Conditioned media were immunoprecipitated with antibodies to NGF or BDNF and electrophoresed on a SDS gel. Results were analyzed on a phosphorimager and are an average $( \pm$ SEM) of three independent experiments.

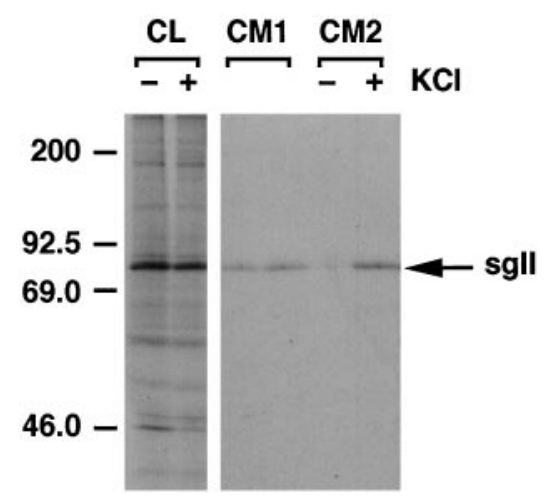

Figure 9. Release of secretogranin II ( $s g I I)$ from hippocampal neurons infected with VV coding for pro-NGF. Eight hours after neurons were exposed to $\mathrm{VV}$, the cells were pulsed for 30 min with medium containing $\left[{ }^{35} \mathrm{~S}\right]$ Cys-Met. The cells were chased for an additional $4 \mathrm{hr}$, after which samples of conditioned medium were analyzed (CM1), and again $30 \mathrm{~min}$ later after the addition $(+)$ or in the absence $(-)$ of $\mathrm{KCl}(50 \mathrm{~mm})$ added to the culture medium $(C M 2)$.

pro-NGF or pro-BDNF with or without V Vs coding for $\alpha 1$-PDX. Figure 11 shows that $\alpha 1-\mathrm{PDX}$ had no detectable effect on proBDNF processing. However, $\alpha 1-\mathrm{PDX}$ did increase the amount of pro-NGF released constitutively into conditioned medium, a result that was similar to those obtained when we monitored proBDNF processing in hippocampal neurons and AtT 20 cells (Figs. $1,3)$. Identical results (data not shown) were obtained when we infected neurotrophin-encoding viruses into a stably transfected AtT 20 cell line overexpressing $\alpha 1$-PDX (Benjannet et al., 1997).

The finding that $\alpha 1$-PDX caused the constitutive release of pro-NGF into conditioned medium suggested to us that $\alpha 1$-PDX might be altering sorting of NGF within the cell, an idea confirmed by immunocytochemistry. Figure $12 \mathrm{~B}$ shows that in AtT 20 cells that stably overexpress $\alpha 1$-PDX, pro-NGF encoding viruses cause the accumulation of NGF immunoreactivity in punc- 


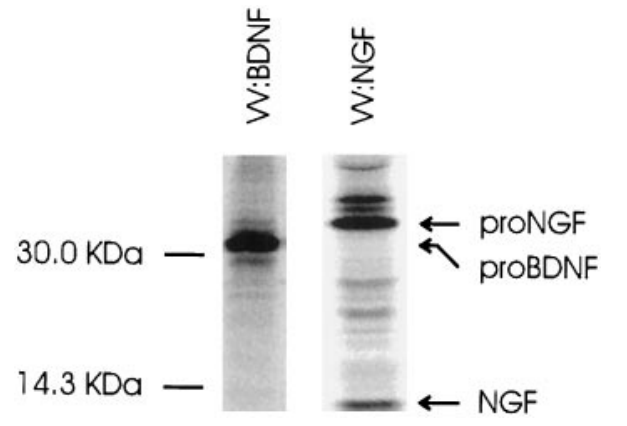

Figure 10. Cold-block experiments. Hippocampal neurons were infected with VV encoding pro-NGF or pro-BDNF for $1 \mathrm{hr}$, and metabolically labeled at $20^{\circ} \mathrm{C}$ for $3 \mathrm{hr}$. Cell lysates were prepared, immunoprecipitated with antibodies to NGF or BDNF, and electrophoresed on SDS gels.

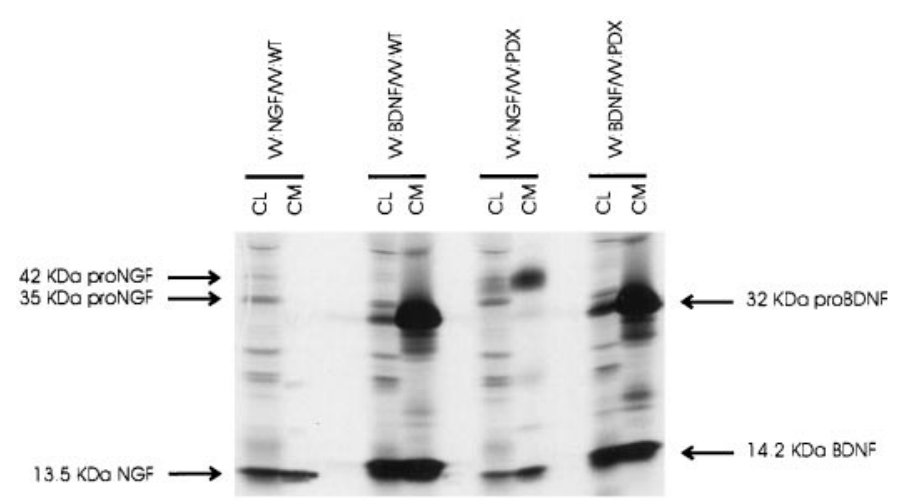

Figure 11. The effects of $\alpha 1$-PDX on pro-NGF processing in AtT 20 cells. AtT 20 cells were infected for $2 \mathrm{hr}$ with VV encoding pro-NGF or pro-BDNF with or without VV encoding the furin inhibitor $\alpha 1$-PDX. Cells were incubated in virus-free medium for $10 \mathrm{hr}$ and metabolically labeled for $3 \mathrm{hr}$. Cell lysates $(C L)$ and conditioned media $(C M)$ were collected, immunoprecipitated, and analyzed by SDS gel electrophoresis.

tate vesicles within the cell cytoplasm and tips of cell processes that does not occur in the absence of $\alpha 1$-PDX. Figure $12 C$ shows that at least some of the NGF in these cells can be released into conditioned medium in response to extracellular cAMP, which is consistent with the protein being sorted to the regulated secretory pathway. Taken together, these data suggest that $\alpha 1$-PDX, which partially inhibits the processing of pro-NGF in the TGN, targets some NGF processing to the regulated secretory pathway, where its release can be promoted by extracellular cues.

Finally, Edwards et al. (1988) reported that cAMP causes the release of NGF from VV-infected AtT 20 cells, data that led them to suggest that NGF is processed and released by the regulated secretory pathway. In that study, cells were infected with an MOI of 10-20, as opposed to 1 MOI in our study. The probable explanation for differences in their results and ours is presented in Figure 13. Immunocytochemical data show that increasing levels of viral infection shifts the intracellular distribution of NGF from a diffuse to a punctate pattern (Fig. 13a). Furthermore, cells receiving $1 \mathrm{MOI}$ do not release NGF in response to cAMP, but cAMP-induced NGF release is seen when cells are exposed to 5 and 10 MOI (Fig. 13b), data that agree with those presented by Edwards et al. (1988). (In the figure, compare CM3 in the presence and absence of cAMP). In contrast, reducing by up to 50 -fold the MOI of VV coding for BDNF had no effect on the punctate localization of BDNF in infected cells (data not shown).
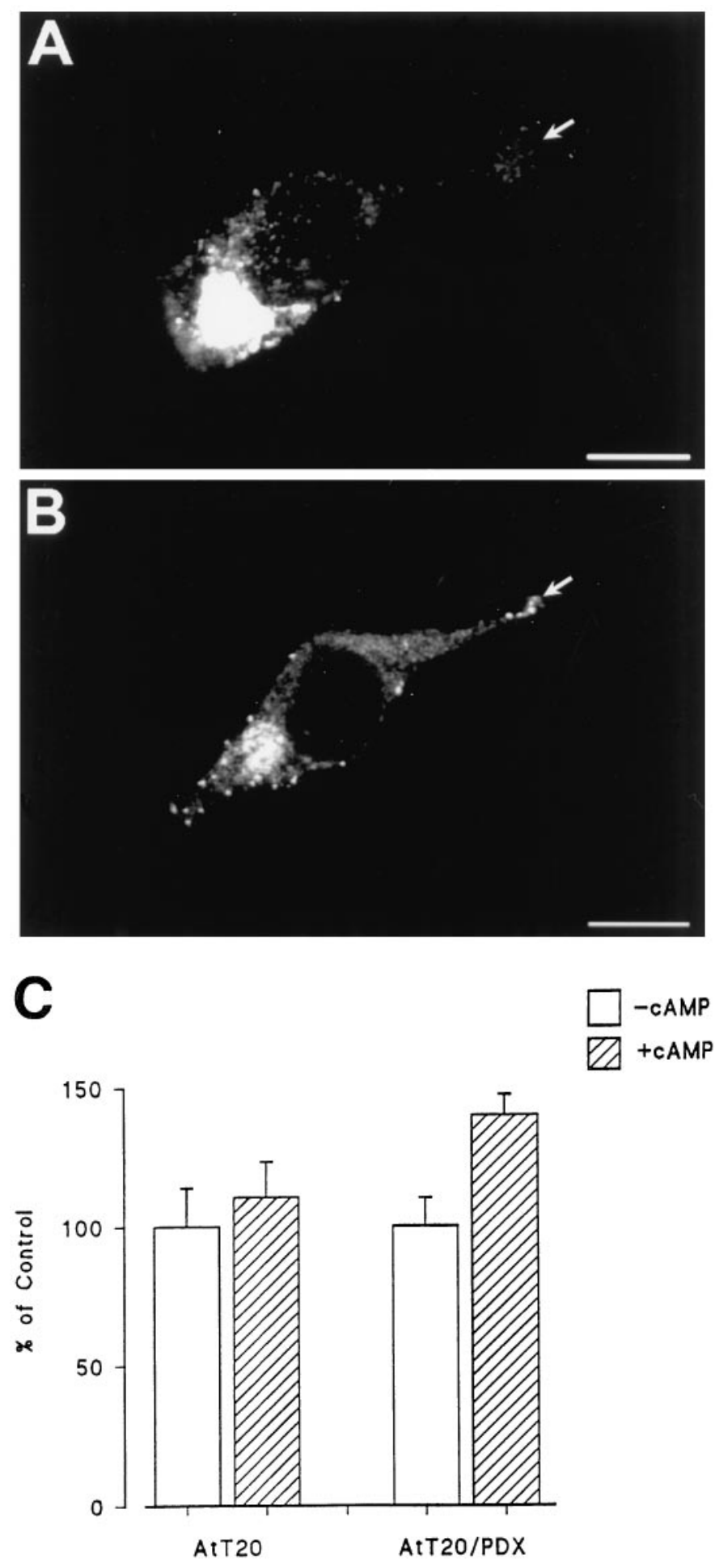

Figure 12. The effects of $\alpha 1$-PDX on NGF sorting in AtT 20 cells. AtT 20 cells $(A)$ or AtT 20 cells that stably express $\alpha 1$-PDX $(B)$ were infected for $1 \mathrm{hr}$ with VV encoding pro-NGF, postinfected for $10 \mathrm{hr}$, and prepared for immunocytochemistry. In $C$, AtT 20 cells with or without stably expressed $\alpha 1$-PDX were infected with VV encoding pro-NGF for $1 \mathrm{hr}$, postinfected for $10 \mathrm{hr}$ in control medium, pulsed with medium containing $\left[{ }^{35} \mathrm{~S}\right]$ Cys-Met for $2 \mathrm{hr}$, chased for $3 \mathrm{hr}$, and treated with medium with or without $5 \mathrm{~mm}$ cAMP for $3 \mathrm{hr}$. Cell lysates and conditioned media were immunoprecipitated and analyzed by SDS-PAGE. Results were analyzed on a phosphorimager and report an average $( \pm$ SEM) of three independent experiments. 
1 M.O.I.

5 M.O.I.

10 M.O.I.

a
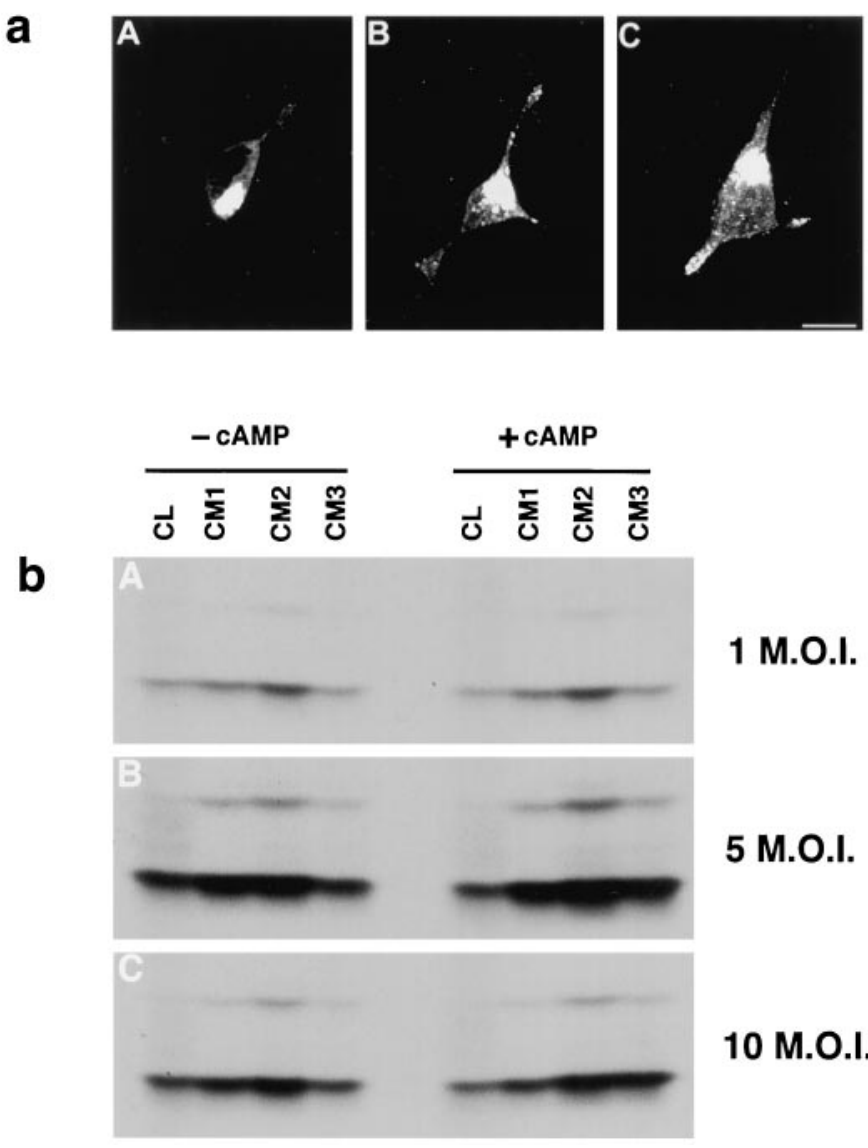

1 M.O.I.

5 M.O.I.

Figure 13. Overexpression of NGF results in missorting of NGF from the constitutive to the regulated secretory pathway. $a$, AtT 20 cells were infected for $1 \mathrm{hr}$ with $1(A), 5(B)$, or $10(C)$ MOI of VV coding for pro-NGF, postinfected for $8 \mathrm{hr}$, fixed, and prepared for immunocytochemistry using an antibody to NGF followed by a CY3-conjugated secondary antibody. Cells were analyzed by confocal microscopy. $b$, AtT 20 cells were infected with $1(A), 5(B)$, or $10(C)$ MOI for $1 \mathrm{hr}$ followed by a $4 \mathrm{hr}$ postinfection and $3 \mathrm{hr}$ incubation in medium containing $\left[{ }^{35} \mathrm{~S}\right]$ Translabel. Conditioned media were collected (CM1), the cells were chased for $3 \mathrm{hr}$, and media was again collected (CM2). 8-bromo-cAMP (5 $\mathrm{mM}$ ) was then added to some cultures, and cells were incubated for an additional $3 \mathrm{hr}$, after which media were collected (CM3) and the cells were lysed $(C L)$. NGF was immunoprecipitated from all samples, and the precipitate was analyzed by SDS-PAGE. Comparison of CM3 samples shows that NGF release can be stimulated by cAMP from cells infected with 5 or 10 MOI but not from cells receiving 1 MOI.

Therefore, sorting of BDNF to the regulated pathway is likely not attributable to concentration effects arising from the level of viral infection.

\section{DISCUSSION}

Pulse-chase studies show that hippocampal neurons and AtT 20 cells retain more newly synthesized BDNF than they release. BDNF immunoreactivity is evident in punctate, vesicle-like structures distributed throughout the cell cytoplasm, including in the tips of cell processes, and cell depolarization induces BDNF release. Thus, BDNF appears to sort primarily to the regulated secretory pathway. In contrast, hippocampal neurons and AtT 20 cells release more NGF than they retain, NGF immunoreactivity is distributed diffusely within the perinuclear cytoplasm, presumably within the endoplasmic reticulum and Golgi apparatus, and depolarization fails to promote NGF's release into conditioned medium. Thus, NGF appears to be processed and released in the constitutive pathway. These results are not unique to the Vaccinia virus expression system because NGF and BDNF were differentially distributed as well within cells transfected with cDNAs coding for GFP-pro-neurotrophin fusion proteins.

Furin appears to cleave pro-NGF in the cells we tested. ProNGF processing is unaffected by cold-block conditions that inhibit the exit of proteins from the TGN (Matlin and Simons, 1983), suggesting that NGF processing occurs within the TGN. In contrast, cold block totally inhibited the processing of pro-BDNF. Pro-BDNF processing likely occurs in immature secretory vesicles after they bud from the TGN, which is an early step in the regulated secretory pathway. Also, $\alpha 1-\mathrm{PDX}$, a competitive inhibitor of furin, increased levels of NGF precursor in conditioned medium, which is consistent with its inhibiting pro-NGF processing within the TGN. $\alpha 1$-PDX did not affect pro-BDNF processing. In the presence of $\alpha 1-\mathrm{PDX}$, NGF immunoreactivity appeared in punctate structures similar to those in cells infected with pro-BDNF encoding viruses, and some NGF precursor was constitutively secreted. Furthermore, depolarization released small amounts of NGF into conditioned medium. These results are similar to those obtained with pro-BDNF in the absence of $\alpha 1-P D X$. Thus, inhibiting furin activity induces some pro-NGF to be sorted to the regulated secretory pathway. Similar effects have been observed for pro-opiomelanocortin (Benjannet et al., 1997).

Cleavage by furin or furin-like enzymes within the TGN may be one factor determining whether neurotrophins are sorted into the constitutive or regulated secretory pathways. Studies with the precursor for egg-laying hormone (pro-ELH) in mollusks may explain how this mechanism could work. Pro-ELH contains bioactive peptides on both the $\mathrm{C}$ - and amino-terminal sides of a furin cleavage site (Sossin et al., 1990). The C-terminal side of the precursor is sorted into the regulated secretory pathway after furin cleavage, and the amino-terminal side is released constitutively, degraded, or sorted into a separate regulated secretory pathway (Jung and Scheller, 1991). In cells with low furin levels, the precursor avoids cleavage, and both sides of the precursor are sorted into the same regulated secretory vesicles (Klumperman et al., 1996). Thus, sorting of the amino-terminal active peptides into dense-core secretory vesicles occurs only in the absence of furin cleavage, and different cells with different amounts of furin sort the same neuropeptide differently.

A similar situation may occur with neurotrophin processing. Sorting into the regulated pathway may require signals within the pro-domain or near the consensus cleavage site. When cleaved by furin, the NGF precursor may lose these signals, and the mature cleaved protein is sorted into the constitutive pathway for release. In that regard, inserting furin-sensitive cleavage sites into proinsulin (Yanagita et al., 1992) and pro-renin (Oda et al., 1991), which are normally processed by the regulated pathway, redirects these proteins into the constitutive pathway. In the absence of furin cleavage, the precursor remains intact, and sorting signals that direct the protein to the regulated pathway become functional. This may explain why pro-BDNF, which likely eludes furin cleavage in the TGN, is targeted to the regulated pathway where its processing appears to occur in secretory granules.

Differences between pro-BDNF and pro-NGF processing may therefore arise because of the furin sensitivity of their proprotein processing cleavage sites. In pro-NGF (Arg-Ser-LysArg $\downarrow$ Ser) the site is highly suited to furin processing, whereas 
the analogous site in pro-BDNF (Arg-Val-Arg-Arg $\downarrow$ His) is less suitable because of the replacement of Ser in the +1 position (P1) of NGF with His in the P1 of BDNF (Seidah et al., 1996a). Sequences with His at P1 show reduced sensitivity to furinmediated cleavage (Ogi et al., 1990; Matthews et al., 1994).

Our results are consistent with this model. In constitutively secreting cells with moderate levels of furin-like enzymes, such as fibroblasts and Schwann cells (M. Marcinkiewicz and N. G. Seidah, unpublished observations), pro-NGF and pro-BDNF are cleaved, with only low levels of unprocessed precursor secreted constitutively. In AtT 20 cells and hippocampal neurons with lower levels of furin (Seidah et al., 1994), pro-NGF is cleaved efficiently, and NGF is released constitutively. When furin cleavage is inhibited with $\alpha 1-\mathrm{PDX}$, pro-NGF is not cleaved efficiently, some sorting occurs into the regulated secretory pathway, where some of the protein can be released by depolarization, and some unprocessed precursor is secreted constitutively. In contrast, proBDNF avoids furin cleavage and is sorted into the regulated secretory pathway, and some unprocessed precursor is secreted constitutively into conditioned medium. Constitutive release of other precursors normally processed in the regulated pathway has also been reported (Kelly et al., 1983; Moore et al., 1983; Brechler et al., 1996)

An increasing number of reports suggest that BDNF, but not NGF, is anterogradely transported within axons in brain neurons to carry out a number of physiological actions [Altar et al. (1997); Fawcett et al. (1998); for review, see Altar and DiStefano (1998)]. Also, BDNF is enriched in a microvesicular fraction of rat brain synaptosomes along with synaptotagmin, a protein associated with synaptic and large dense-core vesicles in nerve terminals (Fawcett et al., 1997). BDNF immunoreactivity is also present in mossy fiber terminals in the hippocampus (Conner et al., 1997; Fawcett et al., 1997) and in large dense-core vesicles of axon terminals in lamina II of lumbar spinal cord (Michael et al., 1997). BDNF can be transported anterogradely in neurons within the visual system (von Bartheld et al., 1996) and released by depolarization in a calcium-dependent mechanism from virus-infected hippocampal neurons (Goodman et al., 1996). Taken together, these data are consistent with BDNF being packaged within secretory vesicles of the regulated pathway. Presumably these granules are targeted to axons, although transport may occur to other parts of the cell as well.

Fewer studies have monitored the processing of NGF in cells containing the regulated pathway. Edwards et al. (1988) reported that AtT 20 cells secrete VV-encoded NGF in response to cAMP, suggesting regulated release. In that study, they infected cells with an MOI of 10-20 as opposed to an MOI of 1 in our study, which explains why their results and ours differ (Fig. 13). Overloading the furin pathway beyond its capacity may drive NGF into the regulated pathway, as does inhibiting furin with $\alpha 1$-PDX (Figs. $11,12)$. In a similar manner, overexpressing $\beta 2$-microglobulin in pancreatic $\beta$ cells drives the protein from the constitutive pathway into secretory vesicles of the regulated pathway (Allison et al., 1991). In contrast, reducing infectivity from 1 to $0.02 \mathrm{MOI}$ had no effect on the sorting of BDNF, although we cannot rule out the possibility that local concentration effects contributed to BDNF's sorting into the regulated pathway.

Heymach et al. (1996) reported that AtT 20 cells release NGF as well as BDNF and NT-3 in response to secretagogues. It may be that in those studies the level of NGF production was above the threshold levels in which NGF is shunted from the constitutive pathway into the regulated pathway. Heymach et al. (1996) used transfection instead of infection, expressed the neurotrophins using a different promoter, and treated cells with secretagogues for a longer time, which may further explain why their conclusions differ from ours. Blochl and Thoenen (1995) hypothesized that there is both constitutive and regulated sodium-dependent release of NGF from neurons. They suggest that release occurs independent of extracellular calcium, which is essential for protein release in the regulated pathway (DeCamilli and Jahn, 1990), including the release of BDNF (Goodman et al., 1996). Canossa et al. (1997) extended these findings by reporting that neurotrophins can also induce neurotrophin release from neurons (also see Kruttgen et al., 1998). These conflicting data need to be investigated further.

Our results provide a mechanism whereby neurotrophins in brain neurons can act either as survival factors or as neuropeptides. When neurotrophins are cleaved by furin, the bioactive peptide may be released constitutively to promote neuronal survival. Perhaps this explains how hippocampal neurons constantly provide NGF to innervating cholinergic neurons in the basal forebrain. In contrast, BDNF may avoid furin cleavage and be sorted into the regulated secretory pathway where it is processed by PC1 (Seidah et al., 1996a) and released in an activitydependent manner similar to other neuropeptides. This may be the mechanism that allows BDNF to alter synaptic transmission, connectivity, and synaptic plasticity in an activity-dependent manner (Ghosh, 1996). Also, perhaps neurons modulate the physiological fates of neurotrophins by regulating furin levels and thus the intracellular sorting of the neurotrophins they produce.

\section{REFERENCES}

Acheson A, Barker PA, Alderson RF, Miller FD, Murphy RA (1991) Detection of brain-derived neurotrophic factor-like activity in fibroblasts and Schwann cells: inhibition by antibodies to NGF. Neuron 7:265-275.

Allison J, Malcolm L, Culvenor J, Batholomeusz RK, Holmberg K, Miller JF (1991) Overexpression of $\beta 2$-microglobulin in transgenic mouse islet $\beta$ cells results in defective insulin secretion. Proc Natl Acad Sci USA 88:2070-2074.

Altar CA, DiStefano PS (1998) Neurotrophin trafficking by anterograde transport. Trends Neurosci 21:433-437.

Altar CA, Cai N, Bliven T, Juhasz M, Conner JM, Acheson AL, Lindsay RM, Wiegand SJ (1997) Anterograde transport of brain-derived neurotrophic factor and its role in the brain. Nature 389:856-860.

Anderson ED, Thomas L, Hayflick JS, Thomas G (1993) Inhibition of HIV-1 gp160-dependent membrane fusion by a furin-directed $\alpha 1$ antitrypsin variant. J Biol Chem 268:24887-24891.

Banker GA, Cowan WM (1977) Rat hippocampal neurons in dispersed cell culture. Brain Res 126:397-442.

Benjannet S, Savaria D, Laslop A, Munzer JC, Chretien M, Marcinkiewicz M, Seidah NG (1997) $\alpha 1$-antitrypsin Portland inhibits processing of precursors mediated by pro-protein convertases primarily within the constitutive secretory pathway. J Biol Chem 272:26210-26218.

Blochl A, Thoenen H (1995) Characterization of nerve growth factor (NGF) release from hippocampal neurons: evidence for a constitutive and an unconventional sodium-dependent regulated pathway. Eur J Neurosci 7:1220-1228.

Brechler V, Chu WN, Baxter JD, Thibault G, Reudelhuber TL (1996) A protease processing site is essential for prorenin sorting to the regulated secretory pathway. J Biol Chem 271:20636-20640.

Bresnahan PA, Leduc R, Thomas L, Thorner J, Gibson HL, Brake AJ, Barr PJ, Thomas G (1990) Human fur gene encodes a yeast KEX2like endoprotease that cleaves pro-beta-NGF in vivo. J Cell Biol 111:2851-2859.

Brewer GJ, Torricelli JR, Evege EK, Price PJ (1993) Optimized survival of hippocampal neurons in B27-supplemented Neurobasal, a new serum-free medium combination. J Neurosci Res 35:567-576.

Bunge RP (1994) The role of the Schwann cell in trophic support and regeneration. J Neurol [Suppl] 242:S19-S21. 
Burgess TL, Kelly RB (1987) Constitutive and regulated secretion of proteins. Annu Rev Cell Biol 3:243-293.

Canossa M, Greisbeck O, Berninger B, Campana G, Kolbeck R, Thoenen H (1997) Neurotrophin release by neurotrophins: implications for activity-dependent neuronal plasticity. Proc Natl Acad Sci USA 94:13279-13286.

Cartwright M, Mikheev AM, Heinrich G (1994) Expression of neurotrophin genes in human fibroblasts: differential regulation of the brainderived neurotrophic factor gene. Int J Dev Neurosci 12:685-693.

Conner JM, Lauterborn JC, Yan Q, Gall CM, Varon S (1997) Distribution of brain-derived neurotrophic factor (BDNF) protein and mRNA in the normal adult rat CNS: evidence for anterograde axonal transport. J Neurosci 17:2295-2313.

DeCamilli P, Jahn R (1990) Pathways to regulated exocytosis in neurons. Annu Rev Physiol 52:625-645.

Dubois CM, Laprise MH, Blanchette F, Gentry LE, Leduc R (1995) Processing of transforming growth factor beta 1 precursor by human furin convertase. J Biol Chem 270:10618-10624.

Edwards RH, Selby MJ, Mobley WC, Weinrich SL, Hruby DE, Rutter WJ (1988) Processing and secretion of nerve growth factor: expression in mammalian cells with a vaccinia virus vector. Mol Cell Biol $8: 2456-2464$

Fawcett JP, Aloyz R, McLean JH, Pareek S, Miller FD, McPherson PS, Murphy RA (1997) Detection of brain-derived neurotrophic factor in a vesicular fraction of brain synaptosomes. J Biol Chem 272:8837-8840.

Fawcett JP, Bamji SX, Causing CG, Aloyz R, Ase AR, Reader TA, McLean JH, Miller FD (1998) Functional evidence that BDNF is an anterograde neuronal trophic factor in the CNS. J Neurosci 18:2808-2821.

Ghosh A (1996) Cortical development: with an eye on neurotrophins. Curr Biol 6:130-133.

Goodman LJ, Valverde J, Lim F, Geschwind MD, Federoff HJ, Geller AI, Hefti F (1996) Regulated release and polarized localization of brain-derived neurotrophic factor in hippocampal neurons. Mol Cell Neurosci 7:222-238.

Haubensak W, Narz F, Heumann R, Lessmann V (1998) BDNF-GFP containing secretory granules are localized in the vicinity of synaptic junctions of cultured cortical neurons. J Cell Sci 111:1483-1493.

Hempstead BL, Rabin SJ, Kaplan L, Reid S, Parada LF, Kaplan DR (1992) Overexpression of the Trk tyrosine kinase rapidly accelerates nerve growth factor-induced differentiation. Neuron 9:883-896.

Heymach JJ, Kruttgen A, Suter U, Shooter EM (1996) The regulated secretion and vectorial targeting of neurotrophins in neuroendocrine and epithelial cells. J Biol Chem 271:25430-25437.

Hosaka M, Nagahama M, Kim WS, Watanabe T, Hatsuzawa K, Ikemizu J, Murakami K, Nakayama K (1991) Arg-X-Lys/Arg-Arg motif as a signal for precursor cleavage catalyzed by furin within the constitutive secretory pathway. J Biol Chem 266:12127-12130.

Jung LJ, Scheller RH (1991) Peptide processing and targeting in the neuronal secretory pathway. Science 251:1330-1335.

Kelly RB, Buckley KM, Burgess TL, Carlson SS, Caroni P, Hooper JE, Katzen A, Moore HP, Pfeffer SR, Schroer TA (1983) Membrane traffic in neurons and peptide-secreting cells. Cold Spring Harbor Symp Quant Biol 2:697-705.

Klumperman J, Spijker S, van Minnen J, Sharp-Baker H, Smit AB, Geraerts WP (1996) Cell type-specific sorting of neuropeptides: a mechanism to modulate peptide composition of large dense-core vesicles. J Neurosci 16:7930-7940.

Kruttgen A, Moller JC, Heymach JV, Shooter EM (1998) Neurotrophins induce release of neurotrophins by the regulated secretory pathway. Proc Natl Acad Sci USA 95:9614-9619.

Loh YP (1993) Mechanisms of intracellular trafficking and processing of proproteins. Boca Raton, FL: CRC.

Luzio JP, Brake B, Banting G, Howell KE, Bragetta P, Stanley KK (1990) Identification, sequencing, and expression of an internal membrane protein of the trans-Golgi network (TGN38). Biochem J 270:97-102.

Matlin KS, Simons K (1983) Reduced temperature prevents transfer of a membrane glycoprotein to the cell surface but does not prevent terminal glycosylation. Cell 34:233-243.

Matthews DJ, Goodman LJ, Gorman CM, Wells JA (1994) A survey of furin substrate specificity using substrate phage display. Protein Sci 3:1197-1205.
Michael GJ, Averill S, Nitkunan A, Rattray M, Bennett DL, Yan Q, Priestley JV (1997) Nerve growth factor treatment increases brainderived neurotrophic factor selectively in TrkA-expressing dorsal root ganglion cells and in their central terminations within the spinal cord. J Neurosci 17:8476-8490.

Moore HP, Walker MD, Lee F, Kelly RB (1983) Expressing a human proinsulin cDNA in a mouse ACTH-secreting cell. Intracellular storage, proteolytic processing, and secretion on stimulation. Cell 35:531-538.

Mowla SJ, Fawcett JP, Pareek S, Seidah NG, Sossin WS, Murphy RA (1997) Differential sorting of nerve growth factor and brain-derived neurotrophic factor in hippocampal neurons. Soc Neurosci Abstr 23:875.10.

Murphy RA, Acheson A, Hodges R, Haskins J, Richards C, Reklow E, Chlumecky V, Barker PA, Alderson RF, Lindsay RM (1993) Immunological relationships of NGF, BDNF, and NT-3: recognition and functional inhibition by antibodies to NGF. J Neurosci 13:2853-2862.

Oda K, Ikeda M, Tsuji E, Sohda M, Takami N, Misumi Y, Ikehara Y (1991) Sequence requirements for proteolytic cleavage of precursors with paired basic amino acids. Biophys Biochem Res Commun 179:1181-1186

Ogi K, Kimura C, Onda H, Arimura A, Fujimo M (1990) Molecular cloning and characterization of cDNA for the precursor of rat pituitary adenylate cyclic activating polypeptide (PACAP). Biophys Biochem Res Commun 173:1271-1279.

Pareek S, Suter U, Snipes GJ, Welcher AA, Shooter EM, Murphy RA (1993) Detection and processing of peripheral myelin protein PMP22 in cultured Schwann cells. J Biol Chem 268:10372-10379.

Rouille Y, Duguay SJ, Lund K, Furuta M, Gong Q, Lipkind G, Oliva AJ, Chan SJ, Steiner DF (1995) Proteolytic processing mechanisms in the biosynthesis of neuroendocrine peptides: the subtilisin-like proprotein convertases. Front Neuroendocrinol 16:322-361.

Seidah NG, Chretien M, Day R (1994) The family of subtilisin/kexinlike proprotein and prohormone convertases: divergent or shared functions. Biochimie 76:197-209.

Seidah NG, Benjannet S, Pareek S, Chretien M, Murphy RA (1996a) Cellular processing of the neurotrophin precursors of NT3 and BDNF by the mammalian proprotein convertases. FEBS Lett 379:247-250.

Seidah NG, Benjannet S, Pareek S, Savaria D, Hamelin J, Goulet B, Laliberte J, Lazure C, Chretien M, Murphy RA (1996b) Cellular processing of the nerve growth factor precursor by the mammalian pro-protein convertases. Biochem J 314:951-960.

Singh N, Birdi TJ, Antia NH (1997) Nerve growth factor production and expression of p75 by Schwann cells and neurofibroblasts in response to M. leprae infection and macrophage secretory products. Neuropathol Appl Neurobiol 23:59-67.

Snider WD, Lichtman JW (1996) Are neurotrophins synaptotrophins? Mol Cell Neurosci 7:433-442.

Sossin WS, Fisher JM, Scheller RH (1990) Sorting within the regulated secretory pathway occurs in the trans-Golgi network. J Cell Biol 110:1-12.

Thoenen H (1995) Neurotrophins and neuronal plasticity. Science 270:593-598

Vollenweider F, Benjannet S, Decroly E, Savaria D, Lazur C, Thomas G, Chretien M, Seidah NG (1996) Comparative cellular processing of the human immunodeficiency virus (HIV-1) envelope glycoprotein gp160 by the mammalian subtilisin/kexin-like convertases. Biochem J 314:521-532.

von Bartheld CS, Byers MR, Williams R, Bothwell M (1996) Anterograde transport of neurotrophins and axodendritic transfer in the developing nervous system. Nature 379:830-833.

Watanabe M, Hirano A, Stenglein S, Nelson J, Thomas G, Wong TC (1995) Engineered serine protease inhibitor prevents furin-catalyzed activation of the fusion glycoprotein and production of infectious measles virus. J Virol 69:3206-3210.

Yan Q, Rosenfeld RD, Metheson CR, Hawkins N, Lopez OT, Bennett L, Welcher AA (1997) Expression of brain-derived neurotrophic factor protein in the adult rat central nervous system. Neuroscience 78:431-448.

Yanagita M, Nakayama K, Takeuchi T (1992) Processing of mutated proinsulin with tetrabasic cleavage sites to bioactive insulin in the non-endocrine cell line, COS-7. FEBS Lett 311:55-59. 